\title{
A mídia impressa e a construção narrativa sobre a AIDS no Brasil no final do século XX: Uma relação perigosa
}

\author{
Printed media and the narrative construction on \\ HIV in Brazil at the end of the 20th century: a dangerous relationship \\ Medios impressos y la construción narrativa de la \\ sida en el Brasil a fines del siglo XX: Uma relación peligrosa
}

Fábio Ronaldo Silva ${ }^{1}$

Raquel da Silva Guedes ${ }^{2}$

\section{Resumo}

SILVA, F. R.; GUEDES, R. da S. A mídia impressa e a construção narrativa sobre a AIDS no Brasil no final do século XX: Uma relação perigosa. Rev. CઐTrópico, v. 44, n. 1, p. 143-162, 2020. DOI: https://doi.org/10.33148/cetropicov44n1(2020)art7

O Brasil é caracterizado como um país de ampla diversidade e com uma população heterogênea. Diariamente, as pessoas tidas como diferentes são desrespeitadas em casa, no trabalho, nas escolas, nos espaços de sociabilidade e, nos últimos anos, pelo governo federal. No dia 5 de fevereiro de 2020, a falta de empatia foi com portadores do vírus HIV, tidos meramente como despesa para a sociedade e para o governo. O discurso não só desrespeitou os Direitos Humanos e dos Cidadãos como reforçou uma construção discursiva implantada no início da década de 1980, quando associava-se os infectados a doentes e a enfermidade a homossexualidade. Essas notícias eram veiculadas pela grande mídia do país e construíam uma identidade errônea da doença, causavam a desinformação e, principalmente, disseminavam o preconceito, as diferenças e a morte através de suicídios. Dessa forma, nosso objetivo é analisar as reportagens que veicularam notícias sobre o HIV e a AIDS em revistas de circulação nacional, pontuando a construção discursiva problemática que ocasionou a deflagração das diferenças e impulsionou o preconceito para com os soropositivos comparando ao pensamento atual repercutido pelas autoridades do governo.

Palavras-chave: Mídia. Preconceito. AIDS. Brasil.

\footnotetext{
Doutor em História pela Universidade Federal de Pernambuco. Atua nas áreas de Gênero, Homossexualidades, Velhices, Mídia Impressa, Ciência e Tecnologia. E-mail: fabiocg@gmail.com ORCID: https://orcid.org/00000002-6004-7340

2 Mestra em História pela Universidade Federal de Campina Grande. Atua nas áreas de Gênero, Ciência e Tecnologia. E-mail: raquel.silva.guedes@gmail.com ORCID: https://orcid.org/0000-0002-3946-2750
} 


\begin{abstract}
SILVA, F. R.; GUEDES, R. da S. Printed media and the narrative construction on HIV in Brazil at the end of the 20th century: a dangerous relationship. Rev. C\&Trópico, v. 44, n. 1, p. 143-162, 2020. DOI: https://doi.org/10.33148/cetropicov44n1(2020)art7
\end{abstract}

Brazil is characterized as a country of wide diversity and with a heterogeneous population. Every day people who are considered different are disrespected at home, at work, in schools, in public places and more recently by the federal government. On February 5th, 2020, a speech by the president did not show any empathy for people with the HIV virus which he stated to be merely " $a$ cost for both society and for the government." This reasoning not only disrespects Human and Citizens' Rights, but also reinforces a premise constructed and implemented in the early 1980s, when those infected were associated with a disease of homosexuality. This news was carried by mainstream media in the country and built an erroneous identity of the disease. It caused misinformation and most importantly spread prejudice, brought division and resulted in deaths by suicide. So, we aim to analyze the reports that were carried in the news about HIV and AIDS in nationally circulated printed press, punctuating discursive constructions which caused increased division and boosted prejudice towards seropositive people, and which are now seen to have parallels in the thinking demonstrated by the authorities in today's government.

Keywords: Media. Prejudice. AIDS. Brazil.

\title{
Resumen
}

SILVA, F. R.; GUEDES, R. da S. Medios impressos y la construción narrativa de la sida en el Brasil a fines del siglo XX: Uma relación peligrosa. Rev. CઐTrópico, v. 44, n. 1, p. 143-162, 2020. DOI: https://doi.org/10.33148/cetropicov44n1(2020)art7

El Brasil se caracteriza por ser un país de gran diversidad y con una población heterogénea. Todos los días, las personas consideradas diferentes no son respetadas en el hogar, en el trabajo, en las escuelas, en los espacios de sociabilidad y, en los últimos años, por el gobierno federal. El 5 de febrero de 2020, la falta de empatía fue con los portadores del HIV, considerado simplemente como un gasto para la sociedad y el gobierno. El discurso no solo no respetó los Derechos Humanos y de los Ciudadanos, sino que reforzó una construcción discursiva implementada a principios de la década de 1980, donde los infectados se asociaron con los enfermos y la enfermedad con la homosexualidad. Estas noticias fueron transmitidas por los principales medios de comunicación del país y construyeron una identidad errónea de la enfermedad, causaron desinformación y, principalmente, difundieron prejuicios, diferencias y muerte a través de suicidios. Por lo tanto, haremos un análisis de los informes que publicaron noticias sobre el HIV y el SIDA en revistas nacionales, puntuando la problemática construcción discursiva que causó la construcción de diferencias y aumentó el 
prejuicio hacia el seropositivo en comparación con el pensamiento actual reflejado por las autoridades del gobierno.

Palabras clave: Medios de comunicación. Prejuicio. SIDA. Brasil.

Data de submissão: 08/05/2020

Data de aceite: 08/06/2020

\section{Introdução}

Eventualmente, escutamos a grande mídia falar sobre a Síndrome da Imunodeficiência Adquirida, conhecida pela sigla AIDS. Geralmente, próximo a festividades que movimentem o âmbito nacional e/ou regional, como o Carnaval, por exemplo. Isso porque, erroneamente, festividades estão ligadas ao aumento da atividade sexual e, consequentemente, de possíveis Doenças Sexualmente Transmissíveis (DST). Mas o que seria a AIDS?

A AIDS é uma doença do sistema imunológico humano resultante da infecção pelo Vírus da Imunodeficiência Humana - HIV. De acordo com o Ministério da Saúde ${ }^{3}$ o vírus ataca o sistema imunológico, esse que é responsável por defender o organismo de doenças. As células mais atingidas são os linfócitos T CD4 $+^{4}$. E é alterando o DNA dessa célula que o HIV faz cópias de si mesmo, multiplicando-se posteriormente e rompendo os linfócitos em busca de outros para continuar a infecção.

A DST responsabiliza-se pelo enfraquecimento do sistema imunológico do corpo, deixando o organismo mais vulnerável ao aparecimento de doenças oportunistas que vão de um simples resfriado a infecções mais graves, como a tuberculose ou o câncer. Nesse entendimento, o tratamento fica prejudicado com a presença do vírus HIV no organismo, uma vez que, o mesmo altera as células de defesa do organismo, infectando e se reproduzindo viralmente. O contágio, por sua vez, dá-se por meio do contato sanguíneo, seja em transfusões, objetos cortantes ou seringas, no contato sexual sem preservativo e de mães infectadas para os filhos, no processo de gestação, parto e amamentação.

Vale salientar que ter o HIV não é a mesma coisa que ter AIDS. Há muitos soropositivos que vivem anos sem apresentar sintomas e sem desenvolver a doença, mas podem transmitir o vírus a outras pessoas quando não tomam as devidas medidas de prevenção.

Por se tratar de uma DST forte, de difícil tratamento e que ainda não tem cura, a AIDS trouxe muitas dúvidas a comunidade. Falar sobre doenças transmitidas por meio do ato sexual é difícil para a sociedade por tocar no patriarcado, na educação religiosa de restrições sexuais e no preconceito. Por isso, historicamente, as DST eram

\footnotetext{
3 http://www.aids.gov.br/pt-br/publico-geral/o-que-e-hiv. Acesso em: 15/03/2020.

4 Linfócito T auxiliar, célula T colaboradora, LT helper (LTh) ou LT CD4+ é um leucócito que atua ativando e estimulando outros leucócitos a se multiplicarem e atacarem antígenos. Assim, coordenam a resposta imune pela liberação de citocinas. Os linfócitos T helper garantem a diferenciação dos linfócitos B em plasmócitos, sendo, portanto, importantes para a produção de anticorpos. Os linfócitos T supressores finalizam a resposta humoral, ou seja, a produção de anticorpos. Já os linfócitos citotóxicos garantem a morte das células estranhas.
} 
tratadas como doenças de rua, castigos divinos, qualidade e/ou atributo de pessoas imorais. Porém, a AIDS, em especial, foi caracterizada como a "doença dos homossexuais", de forma que tal pensamento preconceituoso atrapalhou as pesquisas sobre a doença, a profilaxia e o tratamento, além de despertar, através do preconceito, medo, violência, segregação, desrespeito, morte e abandono, disfarçados em discursos de proteção a população e a saúde, já que se tratava de uma situação nova que assustava socialmente e ainda não tinha maiores esclarecimentos. Segregar era visto como uma forma de proteger e como uma desculpa para limitar as diferenças, já que, o primeiro caso registrado de AIDS no mundo data de $1977^{5}$, década em que a população homossexual tentava adquirir liberdade e direitos.

Recentemente, o assunto AIDS veio ser destaque midiático no Brasil. Dessa vez, não com uma campanha de prevenção ou informativa, mas em um discurso presidencial reverberado no dia 5 de fevereiro do ano de 2020, em que o então Presidente da República, Jair Messias Bolsonaro, mencionou que pessoas portadoras do vírus HIV "são uma despesa para o Brasil, além de um problema sério para elas"6. A fala foi veiculada quando o mesmo defendia a ideia da Ministra da Mulher, Família e Direitos Humanos, Damares Alves, de usar como forma de método contraceptivo a abstinência sexual.

A menção feita pelo presidente foi repercutida internacionalmente e levantou a polêmica sobre o preconceito com que se trata portadores do vírus HIV no mundo. Em resposta, a Associação Brasileira Interdisciplinar de AIDS (ABIA) afirmou que a fala reforça o estigma, o preconceito e a discriminação contra as pessoas que vivem com HIV/Aids. Sustentou, ainda, que políticas de abstinência sexual não reduzem as taxas de infecção pelo HIV e que, ao dizer que as pessoas vivendo com HIV causam prejuízo à sociedade, o presidente autoriza tacitamente o estigma, a discriminação e a violação dos Direitos Humanos ${ }^{7}$, uma vez que, no artigo 196 da Constituição Federal de 1988 consta que "a saúde é direito de todos e dever do Estado"8.

A fala desrespeitosa e preconceituosa do presidente é reflexo de uma construção cultural preconceituosa e desinformada sobre a AIDS, as DST e a Homossexualidade. Essa última, mencionada aqui, por ter sido colocada outrora como veiculadora da doença. Questiona-se então, como esses discursos surgiram e se comportaram no Brasil?

\footnotetext{
O primeiro caso de AIDS registrado no mundo foi no início da década de 1980. A Síndrome da Imunodeficiência Adquirida, contudo, foi descrita em 1981. A primeira vítima da doença foi a médica e pesquisadora dinamarquesa Margrethe P. Rask, que faleceu em 12 de dezembro de 1977 de uma doença que a deteriorou rapidamente. Rask esteve na África, estudando sobre o Ebola, e quando começou a apresentar diversos sintomas estranhos para a sua idade. A autopsia do seu corpo revelou que os pulmões estavam repletos de microorganismos os quais ocasionaram um tipo de pneumonia e vieram a asfixia-la. Contudo, a pergunta que pairava era: ninguém morria em função disso, o que estaria acontecendo? Historicamente, talvez esse seja o primeiro caso descrito de morte por decorrência da AIDS.

6 Disponível em: https://oglobo.globo.com/sociedade/pessoa-com-hiv-uma-despesa-para-todos-diz-bolsonaro-24231125. Acesso em: 15 mar. 2020.

7 Cf. SILVA, F. R.; GUEDES, R. da S. disponível em: https://www.cartacapital.com.br/blogs/dialogos-da-fe/bolsonaro-e-o-discurso-terrivelmente-anticristao-sobre-o-hiv-aids/. Acesso em 15 mar. 2020.

8 http://www.planalto.gov.br/ccivil_03/constituicao/constituicao.htm. Acesso em:15 mar. 2020.
} 


\section{A mídia e a construção narrativa sobre a AIDS no final do século XX}

Falar, estudar e tentar entender a AIDS era uma realidade nova para a década de 1980. Muitos não sabiam lidar, a desinformação era comum, ainda não se conseguia mapear de maneira clara a doença. Esse momento coincide com as datas com o aumento da visibilidade homossexual e como alguns homens foram diagnosticados soropositivos, logo a mídia associou a doença à homossexualidade. Questiona-se, dessa forma, os motivos que impulsionaram os veículos midiáticos a tais informações, e logo, obtemos a resposta de que, o período informado, corresponde a uma reorganização política no Brasil, em que o Regime Militar estava se desfazendo e a imprensa voltava a poder atuar, porém com restrições e sem intencionalidade de ir de encontro as ideologias sociopolíticas da época.

Os principais veículos de notícia na época eram o Jornal do Brasil, Folha de São Paulo e revistas como a Veja e a Istoé, que circulavam entre os brasileiros informando as novidades no país. Tais veículos tinham um tratamento antiético ao falar da AIDS - apresentados e trabalhados em seguida - e que foram rebatidos por Organizações Não Governamentais (ONGs) que foram criadas para tentar informar e ajudar o portador de HIV com campanhas informativas e atendimentos.

É importante lembrar que, nas sociedades pós-industriais que estão em um estágio desenvolvido do processo de midiatização, o campo midiático vai cumprir, de acordo com Esteves (2004, p.168), a "função da mediação simbólica das relações sociais". Assim, é possível afirmar que boa parte das experiências das pessoas com os fatos sociais que acontecem no mundo ocorrem através da mídia. O jornalismo vai contribuir para a percepção do mundo, sendo parte do cotidiano na construção das ideias e opiniões sobre determinados temas e assuntos. A visibilidade midiática que o fazer jornalístico possibilita aos fatos implica levar em consideração essa prática como parte desse fenômeno midiático em conferir uma existência social aos mesmos. Por isso, a produção jornalística (quase sempre noticiada) pode ser percebida como um lugar de disputa em que querem se fazer presentes as vozes públicas, por existir o reconhecimento social de que a mídia é a esfera da visibilidade pública no mundo contemporâneo, é o lugar "onde a realidade se estrutura como referência (FAUSTO NETO, 1999, p. 9). O espaço público é um lugar mediador de sentidos, sendo nele que a sociedade civil enfrenta as tensões de variados olhares sobre os problemas públicos, olhares que pleiteiam a definição de sentidos. 


\subsection{Meu prazer agora é risco de vida}

O jornal francês Le Figaro publicava, em 30 de outubro de 1985, matéria que afirmava ser a "Aids a primeira doença da mídia" demonstrando a grande difusão de notícias pela mídia sobre o assunto e chamava a atenção do público para um novo fenômeno social: a Aids-notícia, pois os veículos de comunicação seriam responsáveis pela construção e circulação das notícias referentes a essa doença, um fenômeno biomédico cuja rede de sentidos não se limitou apenas aos consultórios médicos ou hospitais, pelo contrário, a Aids tornou-se um produto midiático. Veremos então, como esse novo "produto" teria sido mostrado na grande imprensa brasileira.

Em agosto de 1981, no Caderno B, página 6 do Jornal do Brasil, entre a programação teatral daquela semana ${ }^{9}$ e a notícia de um raro documento doado pelo México ao Brasil, encontramos a seguinte matéria: ${ }^{10}$ "Câncer em homossexuais é pesquisado nos EUA" e informa ao leitor que uma equipe médica, composta por vinte especialistas em doenças viróticas, parasitárias, venéreas e em várias formas de câncer, foi montada pelos Centros Nacionais para Controle de Doenças, nos Estados Unidos, para investigar o surgimento de tipos raros, mas mortais, de pneumonia e câncer que estavam acometendo "principalmente os homossexuais masculinos". Segundo a notícia, a enfermidade já havia sido detectada em 10 estados americanos com 108 casos registrados, nos quais a morte havia sido apontada em $40 \%$ dos afetados. O câncer é sempre encarado como doença, doença grave, diga-se de passagem, mas uma enfermidade que não será vista como uma punição ou uma epidemia. Mesmo sob o ponto de vista médico ou da medicina, a doença passava a ganhar visibilidade no país, não era nenhum câncer, mas sobre a Aids que a matéria estava falando.

Essa reportagem sobre a Aids trazida no Jornal do Brasil corrobora com Galvão (2000) que nos informa que as notícias sobre essa achaque chega ao país antes dos primeiros casos identificados. No Brasil, os veículos que publicavam essas reportagens tinham como principal fonte as agências norte-americanas de notícias, o que faz com que a forma como a doença era abordada pela mídia americana exercesse influência nos noticiários nacionais e, consequentemente, no imaginário social relacionado à doença. Principalmente em questões sobre homossexualidade, comportamento e grupos de risco. Isso porque a maioria dos casos notificados de Aids era de pessoas identificadas como homossexuais sustentou a ideia de que estar com HIV era sinônimo de ser homossexual. Não se dizia que tal doença poderia atingir qualquer pessoa, independente de idade, gênero ou prática sexual ${ }^{11}$.

\footnotetext{
9 Cf. jornal do Brasil, 1980, disponível em: http://memoria.bn.br/DocReader/docreader.aspx?bib=030015_10\& pasta=ano\%20198\&pesq= Acesso em 19 mar. 2020.

10 Acredita-se que a disseminação do HIV pelo mundo ocorrera na década de 1970. Quando o periódico Jornal do Brasil publica em 1981 a matéria sobre o caso nos EUA, 20 países já haviam identificando pessoas infectadas pelo HIV, conforme pode ser visto em MANN, Jonathan, TARANTOLA, Daniel J. M. NETTER, Thomas W. (orgs). A Aids no mundo. Rio de Janeiro. Relume - Dumará/Abia/IMS - UERJ, 1993.

${ }_{11}$ No início dos anos 90 o diretor do Programa Global sobre AIDS, da OMS fez um pronunciamento informando que o maior índice de pessoas infectadas em todas as regiões do mundo era heterossexual.
} 
Como nos chama atenção Galvão (2000, p. 26):

[...] no Brasil na década de 80, que marca o início do processo de redemocratização do país, a mídia tem um papel fundamental. Naquele momento, a AIDS, então denominada na mídia por nomes como "doença dos homossexuais" e "câncer gay", era a perfeita notícia para a abertura política do país: remetia à década de 70 no que havia de mais "escandaloso" - sexo e drogas -, sem fazer menção ao contexto político. Nesta leitura da AIDS feita por boa parte da mídia brasileira, um dos principais legados da década de 70 tinha sido um vírus, transmitido por um determinado comportamento, sobretudo sexual. Eram comuns matérias que mencionavam o "desbunde" dos anos 70, a liberalização dos costumes, e como a AIDS foi um "banho de água fria" nas teorias libertárias dos anos 70.

A mídia, mediadora entre as fontes de informação e o leitor, também pode ser percebida como um dispositivo ${ }^{12}$ de enunciação, ao noticiar os casos de Aids $^{13}$ no país e no mundo, fará com que a sexualidade abandone os espaços íntimos e privados tornando-se cada vez mais pública, deixando de ser algo estritamente sexual se tornando uma questão da biopolítica, de interesse dos médicos, dos epidemiológicos, dos sanitaristas, dos psicólogos, etc., que a pensarão de forma discursiva e esses discursos serão explicitados pelo dispositivo midiático que fará a doença existir para a sociedade, como dizia um antigo slogan de uma revista nacional, "aconteceu virou manchete".

Ao considerar a mídia como dispositivo, estamos coadunando com a ideia de Agamben (2014) que, ao dialogar com um conceito foucaultiano, nomeará dispositivo qualquer coisa que tenha, de algum modo, a capacidade de capturar, orientar, determinar, controlar os gastos, condutas, discursos e opiniões das pessoas. Assim, não será apenas o manicômio, a escola, a prisão, a fábrica, a confissão cuja conexão com o poder é evidente, mas também "a caneta, a escritura, a literatura, a filosofia, a agricultura, o cigarro, a navegação, os computadores, os telefones celulares [...] teve a inconsciência de se deixar capturar" (p. 39 - 40). Então, a mídia que dará visibilidade a essa nova doença será também a responsável em transformá-la em uma peste sendo necessária uma "guerra" para poder derrotá-la.

Sontag (1988) enfatiza o quanto às metáforas são geralmente utilizadas em campanhas de saúde que, na maioria das vezes, tratará a doença como algo que invade a sociedade, sendo necessária travar lutas ou iniciar uma guerra na tentativa de reduzir a mortalidade causada na batalha.

12 Como afirma Foucault (2009), o dispositivo é um conjunto de estratégias de relações de força que condicionam certos tipos de saber e por eles são condicionados (p.300)

13 Muitos pesquisadores no Brasil produziram trabalhos sobre a dizibilidade da aids pela mídia no país a exemplo de Fortes et al (1992), Galvão (1992), Cortes et al (1994), Biancarelli (1997), Simões (1997), Ruon (2001), Spink et al (2001), França (2001) e Soares (2001) que trabalharão especificamente com os jornais impressos, Castro (2005), que analisa as revistas e Barata (2006), que analisa a construção e a dizibilidade sobre a aids na televisão, especificamente no Fantástico. 
Ao contrário de outras doenças que causam vergonha, o paciente geralmente não expõe para a família que está doente, mas a Aids fará o corpo do portador do vírus falar, mesmo sem o soropositivo desejar, vai expor a identidade sexual do sujeito que, até então, estava oculta da família, dos amigos, dos vizinhos, dos colegas de trabalho. Quando a doença surgiu e passou a ser diagnosticada pelos médicos e noticiada pela mídia, ela trazia à tona essa identidade, até então trancada dentro de “armários", e classificava o indivíduo como pertencente a um grupo de risco.

No imaginário social, inicialmente, foi denominada de "doença gay", fazendo surgir expressões carregadas de preconceito como "câncer gay" ou "peste gay", a enfermidade foi, muito lentamente, sendo reconhecida como uma doença capaz de atingir todo e qualquer grupo social. No início da descoberta da síndrome, todavia, os homossexuais serão considerados os principais "culpados" pela existência da mesma e a mídia será uma das principais responsáveis em propagar essa ideia.

Na edição 723 da revista Veja, publicada em 14 de julho de 1982, podemos encontrar uma matéria não assinada sobre a "peste gay" intitulada "Mal particular" na qual o médico e professor da Universidade Federal da Bahia, Elsimar Coutinho, alega que "a epidemia da imunodeficiência em questão é causada pelo consumo exagerado de hormônios estrógenos ${ }^{14 "}$ (p.74). A pesquisa foi primeiramente publicada em uma revista especializada de Londres chamada The Lancet e foi relativamente bem aceita pelos pares. O que Coutinho não levou em consideração é que apenas um grupo específico que deseja tomar hormônios, e eles não são homossexuais mas, como chamavam na época, travestis. As mulheres tomam anticoncepcionais, que possui hormônios e, mesmo assim, não desenvolvem o sarcoma de Kaposi ${ }^{15}$. A matéria finaliza apresentando outras possíveis possibilidades da ocorrência da "peste", sendo uma delas "o desgaste do organismo dos homossexuais - minado pela enorme quantidade de infecções a que estão expostos, em razão da natureza promíscua de sua atividade sexual" (p.74). Os saberes médicos vão buscando ligações entre órgãos ou aparelhos vitais com práticas específicas as quais os praticantes serão convidados a abandonar.

Conforme Pereira (2004, pp. 56-57),

O que estas formulações discursivas não pareciam levar em consideração era o intenso processo de transformação por que categorias como "promiscuidade" e tantas outras haviam passado em função da revolução cultural dos anos 60/70. O caráter problemático da troca maior ou menor de parceiros sexuais já havia há muito superado e parecia um verdadeiro pesadelo que questões como essa pudessem voltar à tona. De alguma forma, fazia-se tábula rasa de boa parte das ideias da 'revolução sexual' que havia animado o debate cultural e as práticas comportamentais de boa parte do mundo ocidental desde os anos 60 .

14 http://veja.abril.com.br/acervodigital/home.aspx Acesso em 19/03/2020.

15 Câncer raro que se desenvolve geralmente em idosos. 
A culpabilização dos saberes médicos, religiosos e da própria sociedade pelos gays não seguirem os padrões heteronormativos será uma constante nas notícias sobre o assunto mas, mais interessante é que, de acordo com os jornalistas que escrevem as matérias, bem como boa parte dos médicos que terão a legitimidade para falar sobre a doença, a promiscuidade é uma característica apenas dos gays.

Antes da doença, aqueles que se diziam entendidos, homossexual ou gay muitas vezes não eram bem vistos por assim o ser, agora se associa a infame ideia de que, se é gay é aidético, pois se acreditava que o HIV era passado apenas na relação sexual entre homossexuais, e não uma doença que poderia acometer qualquer ser humano, independente do gênero ou orientação sexual. A mídia no Brasil só passaria a trazer mais notícias sobre a doença em 1983, quando da morte do estilista Marcos Vinicius Resende Gonçalves, o Markito, sendo essa a primeira vítima famosa que morreria em decorrência da Aids no país.

Nascido em Uberaba, em 1953, Marcos Vinicius Resende Gonçalves, desde a escola primária, já gostava de desenhar, enchendo os cadernos com croquis de roupas femininas. A contragosto, cursou Engenharia em Belo Horizonte para agradar os pais, mas não chegou a se formar, pois não se identificava com o curso. Quando falou para os parentes que queria ser costureiro e morar em São Paulo, muitos não concordaram. A família de Marcos morava em uma grande fazenda, herança do avô paterno, onde existia espaço suficiente para morar 15 tios e 100 primos. Após pensarem sobre o assunto, os pais de Marcos resolveram levá-lo a um de 1973, já com 18 anos de idade, Markito foi morar em São Paulo e passou a fazer roupas e vendê-las na famosa Rua Augusta. Foi em uma longa viagem para Nova York que Markito decidiu fazer trajes para a noite.

Na volta para o Brasil, vai trabalhar com alta-costura e o prêt-à-porter tendo como proposta pensar modelos de roupas para determinadas mulheres, aos poucos, ia se tornando um dos estilistas mais importantes do país, vestindo socialites, atrizes, Pat Cliveland, Zezé Mota, cantores e cantoras como Ney Matogrosso, Diana Ross, Simone, Gal Costa e Fafá de Belém. Os trabalhos de Markito eram notícias nos periódicos Jornal do Brasil, Folha de São Paulo e revistas como Veja e Istoé. E seriam essas publicações que noticiariam a sua morte.

No domingo de 5 de junho de 1983, o Jornal do Brasil, na página 28 do caderno 1, seção "Falecimentos" noticiava a morte de

Marcos Vinicius Resende Gonçalves, o Markito, 30, de doença diagnosticada como câncer gay. Em hospital de Nova Iorque, mineiro, de Uberaba, era costureiro e figurinista dos mais famosos do Brasil, chegando a ser chamado de costureiro das estrelas. [...] Vivia há 10 anos em São Paulo e há seis meses começou a ter sintomas da doença. Inicialmente foi tratado pelo médico Paulo Mesquita e depois, aconselhado por outro médico, Jorge Bastos Garcia, a ir se tratar nos Estados Unidos ${ }^{16}$. [...]

\footnotetext{
${ }_{16}$ http://memoria.bn.br/DocReader/DocReader.aspx?bib=030015_10\&PagFis=0\&Pesq= Acesso em 21/03/2020.
} 
A morte do estilista serviu para a mídia contribuir na construção de uma epidemia que estava associada aos homossexuais masculinos que acabavam associados, sem nenhuma distinção, à promiscuidade sendo estes ainda os portadores do novo "mal do século" e por essa prática de vida "irregular" estavam sendo punidos por terem um comportamento perigoso através de atos sexuais considerados divergentes. A transmissão sexual desta doença, tida pela maioria como uma calamidade e a própria vítima é culpada, será mais censurada do que a de outras, isto porque a Aids seria causada pelos excessos e "perversão" e "depravação". Doença infecciosa, na qual a principal forma de transmissão é a sexual, vai expor ao perigo aquelas pessoas sexualmente mais ativas, fazendo com que tal atividade passasse a ser vista como uma punição, um castigo, pois não será perigosa apenas como prática sexual, mas determinado comportamento e desejo sexual não serão considerados "naturais" (SONTAG, 1988).

Outro fator decisivo para os media direcionar os holofotes para essa doença foi que, durante a década de 1980 e começo da década de 1990, personalidades famosas como Lauro Corona, Rock Hudson, Flávio Império, Cazuza e Renato Russo, pessoas que haviam "saído do armário" ou que, pelas enunciações jornalísticas, foram ditas homossexuais ou postas em dúvida, quanto à orientação sexual, eram portadoras do HIV. A partir da morte de Markito, a doença passa a ter, no Brasil, a a visibilidade que, mesmo existindo clinicamente, até então não havia recebido. Quando o Jornal do Brasil, a Folha de São Paulo ou os telejornais falavam sobre o assunto era como se a doença fosse um problema dos outros, seria um "mal de folhetim" conforme Galvão (2000), pois as notícias publicadas geralmente eram sobre os casos que surgiam nos Estados Unidos, país que já havia registrado mais de 500 mortes em decorrência da Aids.

De acordo com Daniel (1991), a mídia brasileira aguardava, ansiosamente, pelo nome da primeira vítima da doença no país para publicar uma manchete já preparada de antemão. E a manchete chegaria em 1983, ano em que teve oficialmente notificados 41 casos de pessoas com Aids, sendo 40 homens e uma mulher.

A edição 771 da revista Veja, publicada em 15 de junho de 1983, também noticiou a morte de Markito. A matéria, de quatro páginas, intitulada "O enigma que mata ${ }^{17 "}$ trazia o seguinte subtítulo: "a terrível síndrome de deficiência imunológica adquirida (AIDS) avança nos Estados Unidos e faz sua primeira vítima no Brasil”. Junto à matéria, vemos a foto do estilista em um cavalo e ao lado, a capa no New York Post, publicado no dia 6 daquele mesmo mês que trazia como manchete principal "Top designer dies of Aids ${ }^{18}$ ". Além de informar sobre a morte do estilista, primeira vítima popularmente conhecida no Brasil a morrer em decorrência da Aids, a matéria que não está assinada, conta a história dos primeiros casos identificados nos EUA pontuando que a doença "ela ataca principalmente homossexuais, como Markito" (p.74). Mas no decorrer da reportagem, afirma que a Aids não é uma doença exclusiva dos gays, aparecendo outros personagens: usuários de drogas, haitianos e

17 http://veja.abril.com.br/acervodigital/home.aspx Acesso em 19/03/2020.

18 "Estilista morre de Aids". 
hemofílicos. O texto é bastante enfático ao afirmar que a Aids tem como principal alvo homossexuais promíscuos.

O Centro de Controle de Doenças de Atlanta chegou a conclusão de que a AIDS não se caracteriza apenas por preferir homossexuais mas, entre estes, ataca principalmente os homossexuais promíscuos, aqueles que trocam frequentemente de parceiros e se permitem outros excessos [...].

Apesar da "promiscuidade" ser a grande causa da infecção, o médico Moacyr de Pádua Vilela, - o qual aparece no texto dando suas impressões sobre a doença, assim como o médico americano Alvin Friedman-Kie, o primeiro a fazer a relação entre as manchas no corpo dos infectados, as bolhas do sarcoma de Kaposi com a Aids, e a médica Valéria Petri, que além de Markito, identificou mais duas outras pessoas infectadas pelo vírus no Brasil -, incomodava-se porque não conseguia explicar o motivo de pessoas heterossexuais, que não eram promíscuas, serem portadoras do vírus e mulheres prostitutas não se tornarem vítimas da doença.

$\mathrm{Na}$ matéria, há ainda depoimentos de pesquisadores querendo saber de onde veio essa nova praga, sendo os países menos desenvolvidos os principais alvos. No texto, são citados Haiti, Cuba e a África. A grande matéria se encerra com a reflexão do pintor e ex-colaborador do periódico Lampião da Esquina ${ }^{19}$, Darcy Penteado que alertava os gays para não se tornarem vítimas de uma regressão moralista que estigmatiza os homossexuais como principais causadores da doença. A questão da "peste" que vem de fora, especificamente dos continentes africano e asiático, é algo presente na reportagem, sendo percebido o preconceito que os americanos e europeus terão com relação aos países subdesenvolvidos sendo reforçado o estereótipo de que negros são seres "primitivos e portadores de doenças mortais" que acometeria todo o globo.

A peste é invariavelmente encarada como uma condenação da sociedade, e quando metaforização da AIDS a transforma numa condenação, as pessoas acostuma-se à ideia de que a doença inevitavelmente se espalhará por todo o mundo. Essa é a utilização tradicional das doenças sexualmente transmissíveis: apresentá-la como castigos impostos não apenas a indivíduos, mas também a todo um grupo (SONTAG, 1988, p. 64).

Logo abaixo da matéria publicada na revista Veja, no final da página, há um box cor de rosa que fala sobre Markito e uma foto do estilista, sorridente e deitado

\footnotetext{
19 O Lampião da Esquina foi um jornal voltado para o público homossexual brasileiro que circulou durante os anos de 1978 e 1981. Nasceu dentro do contexto de imprensa alternativa na época da abertura política de 1970.
} 
numa cama. O texto afirma que Marcos era um paciente bastante difícil de lidar, pois não cumpria as determinações médicas, sendo construída assim, a imagem de uma pessoa que não conseguia seguir regras, nem mesmo aquelas que garantiriam alguns anos de vida a mais por conta do vírus. O estilista viajou para Nova York no intuito de fazer o tratamento da doença. A mãe, Maria Resende foi junto. Segundo relatos, quando chegou à cidade, ele não foi para o hospital da Universidade de Cornell como estava programado. Teriam passado o dia passeando de limusine, no outro dia foram fazer compras e jantar com amigas da mãe. Markito só foi para o hospital porque a situação piorou e, após uma semana de passeios e compras ao lado da mãe, o estilista veio a óbito. De acordo com um amigo, José Vitor Oliva, dono da boate Gallery em São Paulo, "Markito não foi para Nova York para se tratar, foi lá para morrer na cidade que mais amava ${ }^{20 "}$ (p.79). Ou seja, ele preferiu viver os últimos dias de vida na cidade mais populosa dos Estados Unidos, proporcionando grandes e inesquecíveis momentos para a mãe.

Trevisan (1999, p. 429) relembra que,

A partir daí, essa doença, considerada predominantemente americana e rica, invade com sensacionalismo os meios de comunicação e o quotidiano dos homossexuais brasileiros. Os jornais especulam sobre o "câncer guei" (por causa do sarcoma de Kaposi) ou, simplesmente, "peste gay" já que a doença vem atacando sobretudo homossexuais, no mundo todo.

As discussões trazidas pela mídia a respeito da Aids contribuiriam para construir, entre os brasileiros, uma imagem de que a doença vitimava apenas homossexuais ricos e promíscuos que frequentavam grandes metrópoles como Rio de Janeiro, São Paulo ${ }^{21}$, Paris ou Nova York. De acordo com Parker (1994) tal imagem nunca foi questionada nem mesmo pelos especialistas da área médica tampouco pelas autoridades da área de saúde pública, ou seja, os médicos acabaram legitimando o discurso trazido pela mídia e assumindo-o como uma verdade.

Sete dias após a notícia sobre o falecimento de Markito, o Jornal do Brasil traria matéria na qual seriam relatados os dois primeiros casos de “câncer gay" registrados no país. No texto, há relatos de Valéria Petri, professora-adjunta da Escola Paulista de Medicina e mestre em imunologia, que identificou e estava tratando dos dois homossexuais infectados pelo vírus, os quais seriam encaminhados para os Estados Unidos para fazer o tratamento da doença. A médica comenta sobre o pânico entre as pessoas em relação à Aids. E diz que estava recebendo telefonemas de vários Estados do país de pessoas cismadas de estarem contaminadas, fazendo confissões

\footnotetext{
20 http://veja.abril.com.br/acervodigital/home.aspx Acesso em 19/03/2020.

21 No ano de 1983 São Paulo foi o primeiro estado a criar um programa governamental destinado a casos de Aids. A notificação dos casos da doença só passou a ser compulsória três anos depois, ano também no qual o programa de Aids de abrangência nacional começa a ser executado pelo governo federal.
} 
das práticas sexuais para a médica com o objetivo de saber se eram ou não portadoras do vírus. Petri alerta sobre a necessidade de respeitar os dois brasileiros infectados, e afirmara que "eles não estão com a síndrome só porque são homossexuais. Lembro que não são só os homossexuais que podem contrair esse vírus, mas qualquer pessoa que tenha uma resistência de imunologia diminuída, independe da opção sexual ${ }^{22}$ ". Petri diz ainda que não vê a Aids como uma "punição" nem como uma "praga gay".

$\mathrm{Na}$ segunda parte da matéria, temos a fala do imunopatologista e assessor estadual do Secretário de Saúde do Rio de Janeiro, Gilberto Soares. Ele afirma que a Aids não preocupa as autoridades e tal doença não é uma prioridade para o governo. Os males que interessavam ao governo tratar eram doença de Chagas, a tuberculose e os parasitas intestinais, enfermidades que não existiam em países mais desenvolvidos, mas que, no Brasil, ainda continuavam acometendo centenas de pessoas. O assessor afirmou ainda ser os custos para desenvolver pesquisas sobre a Aids bastante altos sendo algo impensável naquele momento, pois até mesmo os Estados Unidos só passaram a investir em pesquisas sobre a doença quando ela se alastrou pelo país. O próprio ministro da Saúde Carlos Sant'Anna afirmaria, em matéria publicada na revista Veja em 14 de agosto de 1985, que a Aids no Brasil "trata-se de uma doença preocupante, mas não prioritária ${ }^{23}$ ”, pois existiam no país, naquele momento, 6 milhões de portadores da doença de Chagas, 8 milhões de pessoas com esquistossomose e quase um milhão de tuberculosos. Assim, não era uma das prioridades do ministério uma atenção especial para a Aids, pois existiam no Brasil apenas 384 casos da doença confirmados. Logo, era uma tolice a população entrar em pânico pois, existia apenas um "verdadeiro lobby" da doença no país, conforme o ministro.

É importante lembrarmos que o surgimento dos primeiros casos de Aids no "país tropical" coincidiu com o crescimento de crises social, econômica e política. Neste período, o Brasil tentava voltar à democracia e tudo isso afetaria na estrutura do sistema de saúde pública sendo limitada a capacidade de ação do governo para responder a demanda de casos de Aids que passaram a surgir de forma exponencial. No ano de 1982, de acordo com dados do Ministério da Saúde, Programa Nacional de DST/Aids, foram identificados 7 casos da doença. O número de pessoas soropositivas chegaria a 4.898 no final da década. Quase cinco mil pessoas que, além da doença, conviviam com o preconceito e a discriminação tanto do próprio governo, que muitas vezes demorava para tomar atitudes que pudessem contribuir em ações para minimizar o sofrimento dos soropositivos quanto da própria sociedade nutridas por informações equivocadas, muitas vezes trazidas pela mídia, que não deixava claro as formas de contágio do vírus e até mesmo o sintoma de garganta inflamada era sinônimo

\footnotetext{
22 http://memoria.bn.br/DocReader/DocReader.aspx?bib=030015_10\&PagFis=0\&Pesq= Acesso em 21/03/2020.

${ }^{23}$ http://veja.abril.com.br/acervo/home.aspx Acesso em 19/03/2020.
} 
de Aids. E encontraremos, em várias matérias, relatos de pessoas afirmando ter deixado de visitar determinados amigos por conta do medo de ser contaminado. Ana, sem sobrenome na matéria, cuidou alguns meses do escultor Paulo Lima de Araújo falecido em decorrência da Aids, e afirmou a Veja na edição publicada em 14 de agosto de 1985 que, ao levar Paulo para o hospital ele foi colocado em uma cadeira de rodas e, na enfermaria as freiras se afastavam com medo de contrair o vírus. Ela mesma afirma que tinha receio de tocar em objetos cujo uso era pessoal.

Algumas vezes, pelo que foi noticiado pela mídia, dito pelos médicos, ou por preconceito por ser homossexual ou por não suportar vivenciar o preconceito por ser portador do vírus da Aids, pelo medo da degeneração física ou até mesmo por vergonha, muitos soropositivos acabaram cometendo suicídio. Apenas em São Paulo, entre os seis primeiros meses de 1985 foram notificados seis casos de suicídio entre pessoas que contraíram a doença. O que mostra que o preconceito e o poder discursivo tem ampla influência no estado psicológico das pessoas em geral e, em especial, daquelas já vulnerabilizadas em decorrência de um enfrentamento pessoal, social e de saúde. O ato do suicídio nesses casos, demonstra que para muitos pacientes era mais difícil conviver com o preconceito disseminado pela sociedade do que com a própria doença.

\subsection{Um pouco de humanidade}

Se o Governo Federal naquele momento não idealizava ações que tornassem a Aids assunto prioritário do Ministério da Saúde, parte da sociedade civil, com toda a solidariedade possível, passou a realizar ações com objetivo de que, no mínimo, as pessoas tivessem mais informações e orientações sobre doenças sexuais transmissíveis (DST) e a AIDS. Assim, Organizações Não-Governamentais (ONGs) com atividades em HIV/Aids desenvolveram projetos de intervenção e assessoria, pesquisa e aconselhamento, trabalhos com crianças e adultos, além de desenvolverem ações em empresas e escolas (KLEIN, 1994).

De acordo com Teixeira (1997) apud Galvão (2000), no ano de 1983 um grupo de militantes do movimento pelos direitos dos homossexuais foi à Secretaria de Saúde do Estado de São Paulo pedir uma posição daquele órgão diante dos casos de Aids que a mídia estava noticiando, sendo então constituído um grupo de trabalho composto por militantes e técnicos de diferentes áreas de atuação.

A criação do programa de Aids do Estado de São Paulo, segundo Teixeira (1997) apud Galvão (2000), foi uma boa combinação entre um governo democrático e a crescente mobilização de setores da sociedade civil através de ativistas dos 
grupos $\mathrm{SOMOS}^{24}$ e o Outra Coisa ${ }^{25}$. Juntos, eles produziram e distribuíram panfletos de advertência em várias ruas da "Paulicéia desvairada". Apesar de serem os primeiros a contribuírem para chamar a atenção do poder público para a doença, os dois grupos tiveram vida curta por conta das dificuldades financeiras, e encerram as atividades entre os anos de 1983 e 1984, respectivamente.

As ações mais contundentes da sociedade civil se deram em 1985, quando foi criado em São Paulo o Grupo de Apoio e Prevenção à AIDS ${ }^{26}$ (GAPA) sendo a primeira ONG/Aids brasileira sendo por ela responsável a advogada Áurea Abbade, redatora do documento que deu origem à Lei 7.660 de 1989 a qual possibilitou a soropositivos sacar o Fundo de Garantia por Tempo de Serviço (FGTS) e o PIS/PASEP para usá-lo no tratamento da doença. Esse será o ano também em que o trabalho de informação e prevenção começa a ser posto de forma sistemática, ganhando dimensão nacional, fazendo o Governo Federal dar atenção a "Aids Brasileira” (GALVÃO, 2000). A criação dessa ONG foi fundamental para articular, um outro tipo de discurso, diferente do que era produzido pela grande mídia e pelo Ministério da Saúde frente à Aids. Além da informação e conscientização, essa ONG teve como principal característica o trabalho relacionado à não-discriminação das pessoas soropositivas, criando um serviço de assessoria jurídica para pessoas com Aids o qual serviu de modelo para outras entidades.

No ano seguinte, no Rio de Janeiro, era criada a Associação Brasileira Interdisciplinar de AIDS (ABIA) que, desde a sua criação, busca articulação com as políticas de AIDS internacionais, bem como a elaboração de análises sobre políticas públicas de saúde relacionadas à doença. Foi a primeira instituição que teve como fundador e presidente uma pessoa assumidamente soropositiva, o sociólogo Herbert José de Sousa, conhecido como Betinho, e o escritor Herbert Eustáquio de Carvalho, conhecido como Herbert Daniel. A ABIA possuía, entre os conselheiros, Dom Mauro Moreli (Bispo de Duque de Caxias), Rubem César Fernandes (que na época era secretário-executivo do Instituto Superior de Estudos Religiosos), Bernardo Galvão (um dos pesquisadores que isolaram o HIV no país). Isso contribuiu para que essa ONG tivesse um "caráter interdisciplinar com uma visão que integrava intervenção cultural e produção de conhecimento, ação política local e atuação no cenário internacional” (GALVÃO, 2000, p. 72).

\footnotetext{
${ }^{24}$ O Somos: Grupo de Afirmação Homossexual, mais conhecido como apenas Somos, foi um grupo em defesa dos direitos LGBT, fundado em 1978, considerado o primeiro grupo brasileiro em defesa desses direitos. O grupo foi formado a partir da publicação do periódico O Lampião da Esquina, chamando-se inicialmente Núcleo de Ação pelos Direitos dos Homossexuais.

25 De acordo com Facchini (2003) por questões de discordância de ideias e propostas, em 1980 o SOMOS passou por um "racha" sendo dividido em três grupos: SOMOS, Grupo Lésbico-Feminista que depois passou a ser Grupo de Ação Lésbico-Feminista (GALF) e o Grupo de Ação Homossexualista que posteriormente passou a usar o nome Outra Coisa. Ainda no mesmo ano, o Outra Coisa se une aos grupos Eros e Libertos formando assim, o Movimento Homossexual Autônomo.

${ }^{26}$ O GAPA tinha como principais articuladores Paulo Roberto Teixeira (um dos criadores do programa de Aids de São Paulo), Paulo Roberto Bonfim (militante de esquerda e técnico em patologia clínica do Hospital do Servidor), Edward MacRae (antropólogo), Áurea Abbade (advogada) e Jean-Claude Bernardet (cineasta, escritor, professor, e um dos articulistas do Lampião da Esquina)
} 
Em contrapartida, as revistas de circulação nacional direta e indiretamente contribuíam para a população a praticar atos bárbaros contra gays e portadores de HIV. No jornal O Dia, em 20 de novembro de 1984 encontramos a matéria "Povo de Sidnei caça os gays por causa da Aids" que explanava sobre a "caça aos gays" tidos como os principais causadores da doença e pelo fato do único Banco de Sangue do país ter informado que foi identificado sangue contaminado no estoque, sendo um homem gay de 27 anos de idade o principal "suspeito" de ter "contaminado o Banco de Sangue administrado pela Cruz Vermelha”. Devido a esse fato, os setores mais conservadores da população, de acordo com a matéria, estavam se vingando. Um dia antes, o mesmo jornal publicou a matéria "Abatido o $3^{\circ}$ gay - Estão matando os travestis a tiros" relatando casos de travestis que foram assassinadas na cidade de Recife-PE. E isso não será um fato isolado, em 4 de setembro de 1985, a Veja publicava, na seção "Comportamento", matéria que tinha como título "A primeira vítima" falando que, por suspeita de Aids a população de Araguari, em Minas Gerais, expulsa o cabeleireiro Evaldo Marques da cidade. Por existir a hipótese de que Evaldo estivesse doente, mesmo não tendo o resultado do exame de sangue, ele foi preso, levado para um hospital e depois banido da cidade. "Se ele aparecer lá vai ser queimado vivo como Joana D’Arc” ameaçava o delegado regional de Uberlândia, Paulo Celso Lucas da Silva. O discurso de ódio construído para expulsar Evaldo foi tão forte que, de acordo com a matéria, os moradores de Araguari diziam que, para se vingar da cidade, o cabeleireiro lambeu as frutas das feiras para contaminá-las, outros diziam que ele nadou na piscina de um clube e experimentou roupas em várias boutiques com a intenção de propagar a doença. Evaldo Marques não se matou, mas os moradores da cidade o mataram simbolicamente.

É importante perceber que o dispositivo midiático é também uma maquinaria de produção de subjetividades. As matérias citadas até aqui, e muitas outras que foram divulgadas e exibidas pela imprensa, contribuíram para a construção de subjetividades que tinham os homossexuais como pessoas perigosas para a sociedade por trazer determinados tipos de doenças. A partir do século XVIII isso já começava a ser feito, mas pela biopolítica, pelos saberes médicos que diziam a homossexualidade como doença. No século XX aos medias não os mostrarão mais como doentes, mas como os causadores do “câncer gay”. E essa produção não foi localizada, foi uma produção em escala internacional e essas subjetividades construídas mudará o olhar das pessoas para com os gays. Se é gay é aidético e também retardará, especificamente no Brasil, para a tomada de decisões dos poderes públicos quanto à doença.

O governo brasileiro demorou para tomar atitudes. A inércia foi justificada por outros problemas na área da saúde que ainda não tinham sido resolvidos, como a malária, a tuberculose, a meningite, dentre outras doenças. Foi utilizada, também como justificativa, as restrições financeiras causadas pela crise econômica, limitando a disponibilidade de recursos para pesquisas, programas educacionais além de cuidados e tratamentos para os pacientes da Aids. Apenas em maio de 1985, foi criado o Programa Nacional de AIDS pela Divisão Nacional de Controle de Doenças Sexualmente Transmissíveis e AIDS, junto ao Ministério da Saúde, ficando esta unidade responsável por desenvolver 
um plano quinquenal para a questão da doença. Aquele período foi marcado por uma abordagem pragmática e técnica sobre a doença na esfera governamental. Utilizando como modelo as iniciativas estaduais e municipais já existentes para desenvolver um plano nacional de prevenção e controle da Aids, à medida que prosseguia a implementação do Programa Nacional de Aids.

O Governo Federal foi tardio, passou muito tempo sem dar importância a existência de portadores de HIV no Brasil, convivendo como se os fatos não existissem, depois resolveu lidar através de uma negação, dentro de um discurso do "não ter o que fazer com os fatos". Consequentemente, veio a fase da divisão por hierarquia e/ou importância, quando os representantes da federação afirmam que há problemas mais urgentes a serem resolvidos no país, seguiram, então, negligenciando atendimento na arguição do não poder financiar pesquisas. Por último e ao mesmo tempo concomitante às ações citadas acima, vieram o apoio ao discurso preconceituoso reverberado pela mídia comum e a negação de informações concretadas para a população.

Só então, a federação não viu mais como sustentar tal postura mediante os aumentos nos números de casos e a cobrança populacional. A partir de então, como mencionado acima, o Governo Federal precisou fazer um plano e esse teve que ser copiado dos governos estaduais que, sob a falta de ajuda federal, já havia lançado um plano de ação. Em seguida, o Brasil veio a financiar pesquisas e laboratórios, contratar profissionais criando O Programa Nacional de Combate à AIDS. Tal assessoria, repaginada e ressignificada, funciona até a atualidade no país. Desde o discurso mencionado pelo presidente Jair Bolsonaro, o Programa corre riscos, podendo, essa conjuntura, mapear um quadro de retrocesso.

\section{Não retroceder}

O Brasil foi considerado referência nos estudos sobre o HIV e sobre a AIDS quando abriu portas para que outros países estudassem seus casos, quando os infectados concordaram em colaborar com as pesquisas servindo de voluntários para análises científicas, quando cantores e atores famosos foram infectados e levaram seu estado de saúde a público mesmo diante do preconceito para encabeçar campanhas, conscientizar os fãs e o público em geral.

Tão logo, grupos assistenciais foram se formando, ONGs foram sendo patrocinadas e o assunto que, inicialmente, foi tratado com o amplo preconceito já descrito, passou a ser desconstruído. A saúde, o tratamento e a acolhimento de um soropositivo passou a ser garantido por lei, a grande mídia precisou modificar a linha editorial e executar campanhas de acolhimento e informações veiculadas pelo Ministério da Saúde e, por fim, o entendimento do que é uma doença viral veio a tentar informar que o HIV nada tem a ver com a homossexualidade.

Trata-se uma luta de informações, testes e pesquisas científicas de quase cinquenta anos que não anularam por completo as dificuldades e o preconceito, mas tentaram o controlar juntamente com a disseminação do vírus. Um caso de saúde pública que foi 
desmerecido em trinta segundos de um discurso mal pensado e muito repercutido. A afirmação presidencial mostrou que, em pleno século XXI, a população ainda encontra-se desinformada, incentivou o preconceito, demonstrou a falta de colaboração do governo, colocou em risco o tratamento e a prevenção do HIV, bem como, desmereceu a porcentagem da população soropositiva do país.

A fala presidencial fere com os Direitos Humanos e dos Cidadãos, impulsiona mortes por falta de tratamento e/ou aumento dos casos de depressão, bem como a segregação dos portadores do vírus HIV. O discurso presidencial, por último, rememora e reconstrói uma fase de desinformação e de preconceito videnciada na década de 1970, demonstrando o retrocesso, anulando os avanços até o presente momento, desmerecendo anos de pesquisas e de empenho por conquistas de espaços e direitos.

Associar os soropositivos a um gasto é desrespeitar o ser humano, a saúde pública e desmentir os dados econômicos brasileiros que comprovam que o percentual de gastos para com os portadores de HIV não ultrapassam seis por cento da cota brasileira. Afirmar que o portador de HIV é um problema para si não é apenas falta de empatia, mas, acima de tudo de humanidade e pode desencadear problemas como depressão e consequências como o suicídio. As doenças virais são contingências mundiais, problema é desencadear preconceito, impulsionar segregação, negar tratamento e profilaxia correta à população.

Respostas ao HIV e à AIDS vêm surgindo ao longo dessas duas décadas do século XXI, se ampliando as opções disponíveis de métodos preventivos para evitar a transmissão a pessoas em risco, bem como novos métodos para pessoas que vivem com o vírus. Os novos métodos de prevenção, além do uso de preservativo por homens e mulheres, incluem um grande leque de abordagens biomédicas, a exemplo das profilaxias pré-exposição $\left(\operatorname{PrEP}^{27}\right)$ e pós-exposição $\left(\mathrm{PEP}^{28}\right)$. A utilização eficaz de distintas abordagens preventivas depende do acesso a informação que os indivíduos e comunidades terão sobre os métodos disponíveis, além da conscientização sobre formas mais eficazes à luz de suas situações específicas e do empoderamento para tomar decisões sobre as possibilidades preventivas que mais tem sentido para suas vidas. Assim, ativistas de HIV/AIDS desenvolveram o conceito pedagogia do tratamento ${ }^{29}$ para ajudar as pessoas a tornar real a promessa de tratamento. De acordo com Gavigan et al., (2016) a Organização Mundial da Saúde (OMS) percebe essa pedagogia como uma forma de "empoderamento" definido como participação significativa nas decisões sobre os cuidados.

A ampliação do tratamento tem grande relação com a questão da prevenção. $O$ que foi vivenciado no passado, no Brasil e em outros países, deve servir como referência para que a pedagogia da prevenção seja percebida com a mesma urgência quanto a pedagogia do tratamento para que seja ampliado o empoderamento não apenas dos que vivenciam o HIV/Aids, mas também aqueles que correm o risco de adquirir o

\footnotetext{
Consiste em um comprimido antiviral por dia tomado antes da exposição ao HIV. Inclui acompanhamento laboratorial de rotina e acompanhamento clínico regular.

28 Após a exposição e durante trinta dias, o indivíduo toma um comprimido por dia com acompanhamento médico por noventa dias.

29 Conceito desenvolvido no final da segunda década do século XX complementando a "pedagogia da prevenção".
} 
vírus. Entretanto, a verdadeira pedagogia da prevenção só ocorre quando existe um sistema de saúde que realmente responda e atenda às necessidades da população. As Organizações Não Governamentais citadas no texto apresentam plataformas on-line que visam a informar a população sobre tal assunto, uma vez que, muitas pessoas ainda desconhecem o método utilizado na Pedagogia da Prevenção. É mantido também um endereço eletrônico para tirar possíveis dúvidas sobre a pré-exposição e a pós-exposição. $\mathrm{O}$ acesso e conhecimento de tais informações não só pode ajudar como também salvar e/ou acelerar o tratamento de pacientes, além de auxiliar na prevenção de maneira didática, empática e compromissada. 


\section{Referências}

AGAMBEN, Giorgio. O amigo \& O que é um dispositivo. Chapecó, SC: Argós, 2014.

DANIEL, Herbert. AIDS no Brasil: a falência dos modelos. In: Daniel, Herbert., PARKER, Richard. AIDS: a terceira epidemia. São Paulo: Iglu, 1991.

FAUSTO NETO, Antônio. Comunicação e mídia impressa: estudo sobre a aids. São Paulo: Hacker, 1999.

GALVÃO, Jane. AIDS no Brasil: a agenda de construção de uma epidemia. Rio de Janeiro: ABIA; São Paulo: Ed. 34, 2000.

GAVIGAN, Kelly. et al. Pedagogia da prevenção: reinventando a prevenção do HIV no século XXI. Perspectiva política. ABIA, Observatório Global / Observatório Nacional de Políticas de AIDS. Novembro, 2015. Disponível em: http://abiaids.org.br/wpcontent/uploads/2015/11/PolicyBrief_portugues_jan2016.pdf

MANN, Jonathan, TARANTOLA, Daniel J. M. NETTER, Thomas W. (orgs). A Aids no mundo. Rio de Janeiro. Relume - Dumará/Abia/IMS - UERJ, 1993.

PEREIRA, Carlos Alberto Messeder. O Impacto da AIDS, a afirmação da “cultura gay' e a emergência do debate em torno do "masculino" - fim da homossexualidade? In. RIOS, Luís Felipe. [et al]. Homossexualidade: produção cultural, cidadania e saúde. Rio de Janeiro: ABIA, 2004.

SONTAG, Susan. Aids e suas metáforas. São Paulo: Companhia das Letras, 1998.

TEIXEIRA, Paulo Roberto. Políticas públicas e AIDS: enfrentando a epidemia no Brasil. In: PARKER, Richard (Org.). Políticas, instituições e AIDS: enfrentando a epidemia no Brasil. Rio de Janeiro: ABIA: Jorge Zahar, 1997.

TREVISAN, João Silvério. Devassos no paraíso: A homossexualidade no Brasil, da colônia à atualidade. Rio de Janeiro, RJ: Record, 1999. 